Article

\title{
Subjective Well-Being, Emotional Intelligence, and Mood of Parents: A Model of Relationships. Impact of Giftedness
}

\author{
Lucía I. Llinares-Insa ${ }^{1, *(0)}$, Ana M. Casino-García ${ }^{2}$ and Josefa García-Pérez ${ }^{2}$ \\ 1 Department of Social Psychology, Faculty of Psychology, University of Valencia, 46010 Valencia, Spain \\ 2 Department of Inclusive Education and Social Community Development, Valencia Catholic University Saint \\ Vincent Martyr, 46110 Valencia, Spain; ana.casino@ucv.es (A.M.C.-G.); josefa.garcia@ucv.es (J.G.-P.) \\ * Correspondence: lucia.llinares@uv.es
}

Received: 11 August 2020; Accepted: 21 October 2020; Published: 23 October 2020

check for updates

\begin{abstract}
The well-being of parents could be either a protective or risk factor for themselves or their children. Our objective is to analyse the affective components of subjective well-being (SWB), emotional intelligence (EI), and parental mood. Parents of gifted children may be a vulnerable group because they face exceptional challenges in raising their children, sometimes with neither educational nor social support. We assess whether parents' EI predicts their SWB and whether positive and negative mood mediate this relationship in two different groups of parents (with or without gifted children). The sample comprised 280 parents. To test the hypotheses, descriptive analysis and structural equation modelling (SEM) were conducted. In both groups of parents, EI predicted SWB, and mood played a mediating role. Parents of gifted children had poorer SWB due to a higher number of negative experiences. Additionally, these parents tended to express more anger. Thus, parents of gifted children are an at-risk group. Our work highlights the need for teachers and social agents to consider families to facilitate the inclusion of gifted students and improve their health and that of their parents.
\end{abstract}

Keywords: subjective well-being; affective balance; emotional intelligence; mood; protective factors; risk factors; parents; gifted students; childhood; adolescence

\section{Introduction}

The relevance of parents in the lives of gifted children is recognised by the scientific community as a whole (e.g., see [1]), and the importance of parental leadership in the emotional development of children and their quality of life is beyond doubt [2,3]. Subjective well-being (SWB) is a key aspect throughout childhood and youth because the cornerstones for mental health are established during these stages [4]. The scientific literature has questioned the happiness of infants and adolescents with intellectual giftedness, obtaining contradictory results [5], but has ignored the well-being of their parents and the negative impact that parents' concerns may have on their well-being [6]. The few studies on this topic confirm the need for additional research. Parents of gifted children present higher levels of anxiety [7] and stress [6] and confront unique challenges [8], sometimes without the necessary social and educational support [9].

Casino-García, García-Pérez, and Llinares-Insa [10], in a study concerning affective components of the SWB of gifted children, found differences between the SWB of gifted students and of unidentified students (children who had not been tested for giftedness or whose scores were negative). More specifically, the authors proposed a theoretical model of relationships that includes emotional intelligence (EI) and its repercussions for SWB mediated by mood. EI plays an important role in 
the academic outcomes of students and their school adjustment [11] and correlates negatively with anxiety, depression, and somatic complaints [12]. EI has also been associated with positive moods [13]. In some studies, the EI perceived from gifted students is less than that from unidentified students [14]. Gifted students have a poorer understanding of their emotions and have fewer meaningful positive experiences [10]. However, research on this issue is limited and has yielded conflicting results [15]. These discrepancies may be attributable to differences in personal and social factors [16]. Here, we attempt to fill this gap by focusing on the analysis of environmental factors such as family. Following Casino-García et al.'s example [10], we specifically analyse the influence of EI and mood on the affective components of parents' SWB.

Family has a considerable influence on student well-being [17]. The emotional difficulties of students are sometimes caused by a lack of attention or an inadequate response of school, family, and the environment to their needs [18]. Emotional competences (e.g., emotional awareness, emotional regulation, and emotional autonomy), life skills, and well-being can be taught and learned [19]. Additionally, the emotional ability of parents influences the emotional development of their children, explaining the importance of the family environment in the development of the emotional regulation of children [20]. Parents are a crucial role model for their children, and there is a significant relationship between parents' EI and their children's, both in their ability to control emotions [21] and in their attention to and understanding of their emotions [22]. Consequently, the education of children and adolescents is more effective if parents play a greater role at home and if the relationship of the parents with the school is strengthened [23].

Despite the crucial role of parents in the education of gifted children, analyses of parents' SWB, EI, and mood are lacking [24]. Research has examined the perceptions of parents regarding how families function (e.g., [25]); the perceptions of gifted students of their family environment and its relationship with their interpersonal skills and interactions with classmates (e.g., [26]); the relationships between the identified child and siblings (e.g., [27]); and parents' psychological well-being, namely, their levels of anxiety and stress (e.g., [6,7,9]). No study has analysed the SWB, moods and EI of parents of gifted students. Thus, we aimed to determine the SWB, specifically affective well-being, EI, and mood of this group of parents and to test a model of the mediating roles of different moods in the relationship between EI and SWB (Figure 1). We evaluated this model using both parents of gifted children and adolescents and parents of unidentified children and adolescents.

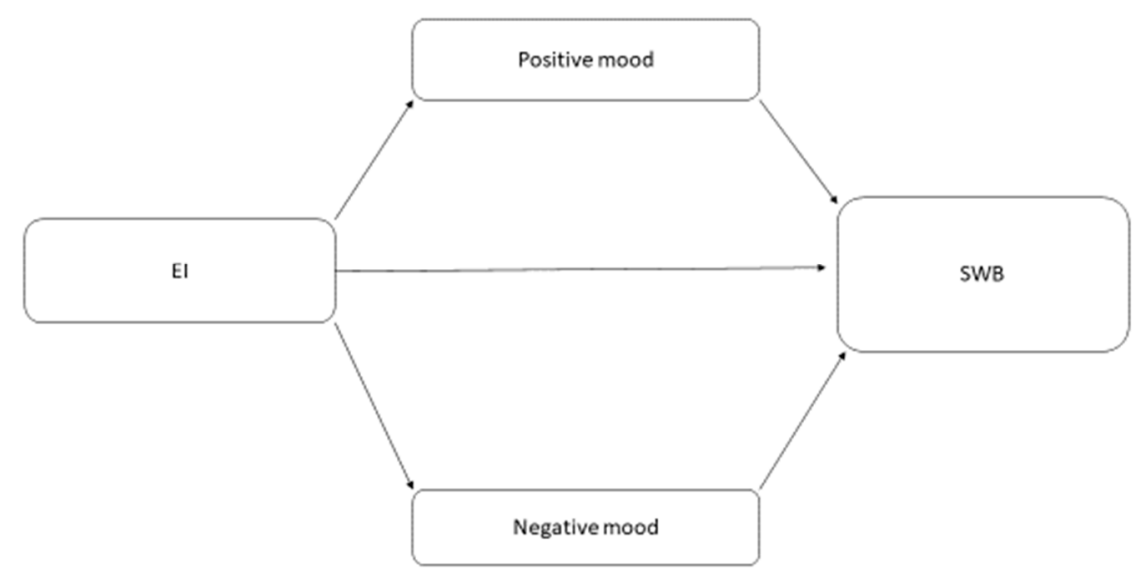

Figure 1. Hypothesised conceptual model.

The current research literature on SWB does not consider the parent group, more specifically, the parents of children with intellectual giftedness. Filling this gap is important for several reasons. First, research has shown the importance of parents' characteristics in their children's development [28]. The family unit is particularly relevant for gifted students, particularly those who present emotional difficulties [29]. Second, this group of students shows added difficulties in their formation process [30], 
leading to stress and poor physical and psychological health [9]. Occasionally, this group of students also presents lower EI (e.g., [10]) and, due to a lack of emotional competence skills, are more likely to generate negative moods, implying high levels of long-term stress [31] that will affect their families [32]. From the point of view of positive psychology, personal health promotes healthier societies [33], and the family is a protective factor in the prevention of risk behaviours [34]. Third, generating a society in which people's character traits are enhanced [35] and talent is developed [36] is desirable. Fourth, the relationships among the affective dimensions of SWB, EI, and mood in parents of unidentified children and parents of gifted children must be explored. The literature has shown that the relationships of the proposed model can differ depending on whether the child has or has not been identified as gifted [10]. To understand how these relationships develop, we need to study and test this model in parents of identified and unidentified children.

\subsection{Subjective Well-Being of the Parents of Gifted Students}

The family is the main context of human development and provides a space to grow as adults with a good level of well-being [28]. It is important to differentiate between psychological and subjective well-being. Psychological well-being is a desirable quality, according to external and normative criteria, while SWB results from a valuation based on internal criteria that are personal [37].

SWB involves a general assessment of life in a set time period and is unique to each individual, as it depends on his or her experiences and not on objective indicators [33]. SWB has three different elements: life satisfaction judgements (cognitive component), low negative affect (NA), and high positive affect (PA) [38]. Following the model of Diener et al. [39], our study focuses on the emotional, hedonistic, or affective balance that each person shows between these two affective dimensions: positive and negative experience and feelings. Affective well-being correlates with other measures of general well-being [40] even with global life satisfaction judgments [41].

Various studies have concluded that paternity is associated with a higher sense of well-being [42], while other research tends to indicate that the relationship between well-being and paternity is variable [43]. More than likely, the well-being and happiness of parents depend on different factors and conditions that act as moderators [44]. For example, children's problems (e.g., chronic diseases, disability, depression, behavioural problems, and drug abuse) are likely an important predictor of their parents' well-being. Children with problems feel greater stress and have more negative experiences in their daily lives. When children are difficult and/or highly sensitive, their parents have lower levels of well-being. However, because this condition is partly hereditary, an alternative explanation is that parents, as well as their difficult children, can be genetically inclined to experience a lower level of well-being. Additionally, the lower level of well-being of parents can be related to more negative behaviours from parents and affect their children's immediate and longer-term results.

People with intellectual giftedness with more problems seem to have more worrying features in their family lives (e.g., physical difficulties, traumatic separations, frequent changes of residence, and excessive parental concern) [29]. A large percentage of students with intellectual giftedness present overexcitability [45]. Additionally, there are twice-exceptional (2e) students in whom intellectual giftedness co-occurs with some learning or emotional disability or physical handicap [46]. As a group, their involvement in bullying $[47,48]$ and cyberbullying $[49,50]$ situations is greater. Moreover, the dissatisfaction of the parents of gifted children with the learning environment at school has been discussed on different occasions and in different contexts (e.g., [51]). The idea that these children and young people do not need help because of their greater intellectual capacity is one of the biggest misconceptions that this group has had to endure in some educational environments [52]. Garn, Matthews, and Jolly [53] reported that parents of gifted students frequently see the learning environment as non-challenging and with little motivation and modify the tasks and duties to satisfy the learning requirements of their children. Many families tend to be focused on their children [54].

This leads us to believe that the parents of these students may be a vulnerable group. Additionally, most models analysing the protective and vulnerable factors affecting adolescents include family as a 
fundamental element [32]. According to Nelson et al. [44], future researchers should identify which parents are at particular risk of a lower state of well-being so that they can be provided more specific interventions. Nevertheless, we have found few studies on the well-being of parents of gifted students, and all of these studies analyse psychological well-being.

For example, Rimlinger [7] finds higher levels of anxiety and stress in Australian and American parents of gifted students than in parents of a normative sample, regardless of whether their children present double exceptionality or not. Unlike Australian parents, the scores of North American parents for stress and anxiety are equal to those of parents of children with a developmental delay, although only scores for anxiety reach the level of significance. The following significant predictors of stress were identified: problematic behaviour of the child, problems of the child with classmates, low scores of the child on prosocial behaviour, and a low level of trust of parents in the teacher of their child in terms of how teachers respond to educative, emotional, and social necessities and communication with parents.

In children with non-progressive neurodevelopmental disorders, in addition to infant behaviour issues, a higher degree of attention focused on the family is an important indicator of parental well-being (fewer feelings of anguish and depression when professional assistance is provided to the family) [55]. However, in McDowall's study [6] mothers of students with high capacities exhibited frustrations with the educative system, talked about a lack of understanding from families and professionals, stigmatisation and social isolation, and complained about a lack of support. In addition, Free [9] reported a lack of social and educative support and stigmatisation of parents of children with intellectual giftedness. Nevertheless, no work has focused on analysing the SWB of parents of gifted children.

Hence, considering that the family is not a passive receptor but rather an intrinsically active system, any type of tension affects how a family unit works. Psychosocial development that does not adapt to children becomes a new stress factor for the family unit [32], leading us to consider the group of parents of gifted students as vulnerable or at risk in terms of emotional well-being. Thus, we formulate Hypothesis 1 (H1).

Hypothesis 1 (H1). The parents of gifted children have lower subjective well-being than those of unidentified students.

\subsection{Mood of the Parents of Gifted Students}

For parents, children are a source of positive and negative feelings [56]. Many adults consider having children to be one of the most rewarding aspects of their lives (e.g., [57]), but they also view parenting as one of the most difficult challenges (e.g., [58]). Unhappy parents perceive negative emotions. When they experience more positive emotions, they experience happiness and joy [44].

Parents of gifted children and adolescents may often experience negative feelings due to issues regarding their children's ability to build relationships [59], their children's lower well-being [10], the lack of educational adjustment [60], the lack of support and teacher training [61], and the participation in bullying and cyberbullying [49]. They can also experience these feelings even more intensely than the parents of unidentified children [45]. This would generate, according to Metler and Busseri [62], lower overall well-being for parents.

Moods refer to global affective states, without a specific cause or motive or clear beginning [63], as if they were reminiscent of emotions [64], and are impacted by various personal (e.g., coping) and social (e.g., peer relationships or social support) variables [65]. The moods of parents of gifted children could be more negative than those of parents of unidentified because gifted children feel sadder than unidentified ones [10]. The parents of gifted children feel alone, misunderstood, and do not receive enough educative and social support [6,9]. Given the above reasons, our second Hypothesis $(\mathrm{H} 2)$ is as follows: 
Hypothesis 2 (H2). Parents of gifted children perceive negative feelings more frequently and with more intensity than parents of unidentified children; overall, their mood is more negative than that of parents of unidentified children.

\subsection{Emotional Intelligence of Parents of Gifted Children}

Salovey and Mayer [66] define EI as "the recognition and use of one's own and others' emotional states to solve problems and regulate behaviour" (p. 189). Thus, emotionally intelligent individuals can (a) perceive emotions accurately, (b) leverage emotions to improve thinking, (c) understand emotions and their meaning, and (d) efficiently control and manage their emotions and others' emotions [67]. EI combines affective and cognitive processes to allow adaptation to and resolution of everyday conflicts [68].

Most research analyses how parents influence children's EI. For Eisenberg, Cumberland, and Spinrad [69], socialisation of children's emotions and emotion-related behaviour by parents can be categorised as follows: “(a) parental reactions to children's emotions, (b) socializers' discussion of emotion, and (c) socializers' expression of emotion" (p. 245).

Research supports that parents develop and model children's emotional competencies within the family. The EI components in children that are most affected by parental styles are stress management and mood, and levels of these components are better when parents have a more democratic style [70]. Another area of research focus is the effect of parental EI on the child's development and behaviour (e.g., [71]). Parents who are sensitive to their children's needs tend to have emotionally intelligent children [72]. The level of EI of parents is related to a psychologically familiar climate [73]. Regulated mothers tend to express more positive emotions and less negative ones [21]. By minimising stress and encouraging self-acceptance, a caregiver who is sensitive to and responsive to an infant's cues will encourage high EI in children and an improved ability to regulate emotions [70]. Even in very adverse situations, a positive correlation has been found between social inclusion and children's ability to understand others' feelings and ideas and the parent's ability to guide children [74].

A clear relationship exists between parents' self-reported EI (father-mother) and that of their children. Specifically, Cumberland-Li, Eisenmberg, Champion, Gershoff, and Fabes [21] point out that the capacity of parents to control their emotions is related to their children's ability to do so. Using self-report measures, Sánchez-Núñez, Fernández-Berrocal, and Latorre [22] observe that higher levels of attention and clarity among parents are related to higher levels of these same dimensions in their children, but this relation does not hold for levels of repair. The authors attribute this fact to the possibility that regulation strategies could still be in development. In addition, the biggest predictor of EI self-reported by children is the perception they have of their parents' EI. This perception correlates with the estimations parents have of their own EI.

Few studies have focused only on fathers' EI, and these tend to focus on the transition to parenthood. Childcare transforms parents' lives; individuals with children have a different developmental path than those without. This change does not affect personality, for example, but it likely impacts emotional competence [75]. However, no study has analysed changes in parental EI throughout children's infancy and adolescence. Additionally, the complexity of raising children may vary depending on specific situations or characteristics of the child. This finding may also lead to changes in parental EI (e.g., [76]) and generate intense demands on parents, who experience higher levels of stress than parents of developmentally typical children [77]. Investigations of parental EI are scarce, and when researched, EI is considered a mediating variable or related to some other variable that is considered relevant. If this variable is true for parenting in general, it is even more pronounced for parents of gifted children.

Many of these parents find a lack of resources to manage life with a gifted child [78]; consequently, they suffer stress [7], and develop emotional problems [8] and frustration [6]. However, no study has focused on the EI of parents of gifted students. Gifted students exhibit higher adaptability, lower stress management, and lower impulse control than the normal sample [79], making gifted 
students more vulnerable. Casino-García et al. [10] found significant differences between identified and unidentified students in clarity; gifted students understood their emotions less and felt sadder. Unfavourable parental reactions to children's negative emotions may be associated with negative emotionality and low social and emotional competence in children [69], explaining why understanding the socio-emotional needs of gifted children and how to meet these needs via parental education programmes have positive results for parents and children [24]. According to the model of Zeidner, Matthews, Roberts, and MacCann [80] on the development of emotional competencies, parental and child influences are bidirectional. The image projected by parents to their children around emotional skills affects the family environment, which, in turn, affects the development of the emotional skills of all family members.

Initially, there should not be differences between EI perceived from parents of gifted students and those of unidentified students. However, as parents confront the demands of their children and the associated challenges, the lower clarity of children's EI and the correlation between EI perceived from parents and children will become apparent, leading to Hypothesis 3 (H3):

Hypothesis 3 (H3). The perceived emotional intelligence of the parents of gifted students is lower than that of parents of unidentified children, specifically in clarity.

\subsection{Emotional Intelligence and Well-Being of Parents}

EI has been linked to various personal and social success factors such as SWB [81]. Using effective emotional regulation strategies helps improve satisfaction, happiness, and well-being [82]. Some studies have documented a relationship among these components (e.g., [83]), and others have attempted to explain the causal mechanisms by which EI influences well-being [84]. Zeidner, Matthews, and Roberts [85] state that EI influences SWB because it aids the development of coping mechanisms to manage challenges and problems, reduces negative emotions and increases positive ones, and promotes the regulation of emotions that improve SWB [86]. This finding has led to a large body of research in the field of intervention to increase EI and SWB (e.g., [87]), and some of these studies have focused on parent training (e.g., [86]).

A positive impact of EI on stress control has been documented [88], and EI is a predictor of SWB in adults [81]. This finding is the fundamental reason why, in this paper, we assume EI is a factor that promotes well-being because EI refers to skills that can be taught to improve coping mechanisms in difficult situations [89]. In this sense, EI is a key precursor to feelings associated with well-being. Thus, Hypothesis 4 (H4) is proposed.

Hypothesis 4 (H4). Emotional intelligence predicts subjective well-being.

\subsection{Subjective Well-Being, Emotional Intelligence, and Moods in the Parents of Gifted Children and Adolescents}

The emotional components of SWB are more reactive to situational influences and are more easily modified [90]. Studies on this topic highlight the importance of personal circumstances [91]. Parents have a higher degree of emotional ups and downs than other adults, and parenting can sometimes be a source of worry and stress [52] that reduces well-being. Nelson et al. [44] propose a model in which different psychological mechanisms impact the correlation between parenthood and well-being, including positive and negative emotions. These authors contend that research on how these psychological mechanisms explain the association between parenthood and well-being needs to be further developed.

In brief, parents of gifted students, as we have observed, may be subject to a major number of more negative and more intense emotions. These negative emotions and moods tend to have a longer duration and impact than positive ones [40]; a negativity bias exists [92]. EI can reduce the occurrence 
and duration of negative emotions and mood swings (e.g., [93]). Furthermore, the frequent use of behavioural strategies and approaches to regulate negative mood swings has been associated with a higher degree of life satisfaction and emotional well-being. These strategies include behaviours or actions that imply active ways to regulate negative mood, such as being outdoors or socialising, sharing feelings with others, and seeking advice [82]. Some researchers suggest that the efficacy of these strategies depends on their focus on confronting and reducing aversive effects of negative emotions [91] or increasing positive ones [94]. Both approaches, through different paths, describe the increase in well-being.

In this study, we follow the model proposed by Casino-García et al. [10], who found that in children and adolescents, moods mediate the relationship between EI and SWB. The literature on the subject highlights that moods affect cognitive judgements and influence the interpretation of ambiguous stimuli [95]. It is common for parents of gifted children to face unclear situations that require a high degree of interpretation. Rinn [96] reports that gifted children and adolescents experience the same milestones and developmental tasks as other children, but their subjective experience is qualitatively different, and they have more difficulties in coping with it. Gifted children have different educational needs than their non-gifted peers [97]. The importance of positive and negative emotions and their impact on well-being in adults has also been documented [98]. This research posits that positive and negative moods mediate the relationship between EI and SWB and that this relationship differs between the parents of gifted students and those of unidentified students.

Hypothesis 5 (H5). The relationship between emotional intelligence and subjective well-being is mediated by moods.

Hypothesis 6 (H6). Moods differently mediate the relationship between emotional intelligence and subjective well-being in parents of gifted children and in parents of unidentified children.

\section{Materials and Methods}

\subsection{Procedure and Participants}

This study was approved by the Ethics Committee of the Catholic University of Valencia (UCV/2015-2016/05). We used convenience sampling [99], which is widely used in both quantitative and qualitative studies. Convenience sampling is a non-probability method of sampling in which the sample is chosen using practical criteria. We selected parents of gifted children depending on ease of accessibility and availability. We contacted associations of families with gifted children and, in addition, parents of gifted children who do not participate in associations. The criterion for inclusion was a gifted diagnosis by a legally recognised specialist. Parents of the unidentified children were selected such that their characteristics were similar to those of gifted children (age, grade, income, geographic area, sex, type of school, etc.) and they did not have a gifted diagnosis. The total sample comprised 280 parents in two samples (parents of gifted and unidentified students). Sample 1 comprised 163 parents of gifted students $(63.8 \%$ female and $36.2 \%$ male) ranging in age from 31 to 65 years $(\mathrm{M}=43.62$; $\mathrm{SD}=4.87)$. Most were married $(93.9 \%)$ and had two children $(60.7 \%)$, with one $(80.4 \%)$ or two children $(17.8 \%)$ identified as gifted. Additionally, $64.8 \%$ of the parents had completed university. Sample 2 comprised 117 parents of unidentified Spanish children (81.2\% female and 18.8\% male) ranging in age from 34 to 57 years $(\mathrm{M}=44.79 ; \mathrm{SD}=4.55)$. Most of the parents were married $(88 \%)$, had two children $(65 \%)$, and had a university degree (62.4\%).

\subsection{Measures}

The parents voluntarily completed an informed consent form and a battery of questionnaires: The Scale of Positive and Negative Experience (SPANE) [100], Trait Meta- Mood Scale-24 
(TMMS-24) [101], and Mood Questionnaire [63]. We followed the instructions of Podsakoff, MacKenzie, and Podsakoff [102]. Moreover, we excluded participants with missing data (0.1\%).

First, to analyse SWB, we used the Spanish adaptation of the Scale of Positive and Negative Experience (SPANE [103]) by Cassaretto and Martínez [104]. This scale has six items that assess positive experiences ("Pleasant") and six items to assess negative experiences ("Bad"). Moreover, it can also be used as a single factor of affect balance. The twelve items are scored on 5-point Likert scales ranging from 1 (never) to 5 (always). Alpha showed high internal consistency (single factor in total sample $\alpha=0.91$, sample $1 \alpha=0.91$, sample $2 \alpha=0.90$; positive total sample $\alpha=0.93$, sample $1 \alpha=0.93$, sample $2 \alpha=0.93$; negative total sample $\alpha=0.85$, sample $1 \alpha=0.82$, sample $2 \alpha=0.86$ ).

Second, EI was assessed using the Spanish adaptation of TMMS of Fernández-Berrocal, Extremera, and Ramos [105]. The TMMS contains three scales: attention (e.g., "I pay a lot of attention to how I feel"), clarity (e.g., "I almost always know exactly how I am feeling"), and repair (e.g., "No matter how badly I feel, I try to think about pleasant things"). TMMS is a scale with 24 items and is assessed on a five-point Likert scale ranging from 1 (strongly disagree) to 5 (strongly agree). The scale reveals high levels of reliability (general factor in total sample $\alpha=0.84$, sample $1 \alpha=0.85$, sample $2 \alpha=$ 0.82 ; attention in total sample $\alpha=0.86$, sample $1 \alpha=0.88$, sample $2 \alpha=0.84$; clarity in total sample $\alpha=0.87$, sample $1 \alpha=0.88$, sample $2 \alpha=0.87$; repair in total sample $\alpha=0.86$, sample $1 \alpha=0.87$, sample $2 \alpha=0.86$ ).

Third, the adaptation of the Mood Questionnaire [63] by Górriz, Etchezahar, Pinilla-Rodríguez, Giménez-Espert, and Prado-Gascó [106] was used to assess mood. This scale has been validated in Spanish adults and scale includes 16 items that assess the frequency of positive (e.g., "I feel encouraged") and negative moods (e.g., "I feel terrified"). Negative mood items also evaluate fear ("I feel nervous"), anger ("I feel furious"), and sadness ("I feel unhappy"). The items were answered on a three-point Likert scale $(1=$ never to $3=$ often). The scale demonstrated high reliability and validity in our samples for positive mood (happiness in total sample $\alpha=0.77$, sample $1 \alpha=0.79$, sample $2 \alpha=0.72$ ) and negative mood (total sample $\alpha=0.88$, sample $1 \alpha=0.90$, sample $2 \alpha=0.86$ ): fear (total sample $\alpha=0.70$, sample $1 \alpha=0.70$, sample $2 \alpha=0.71$ ), anger (total sample $\alpha=0.83$, sample $1 \alpha=0.86$, sample $2 \alpha=0.75$ ), and sadness (total sample $\alpha=0.76$, sample $1 \alpha=0.80$, sample $2 \alpha=0.69$ ).

\subsection{Data Analysis}

First, we determined the levels of EI, mood, and SWB of parents. For the analysis, we calculated descriptive statistics (mean and standard deviation) and the $t$-test. We aimed to analyse the degree of EI, mood, and SWB and whether levels varied among parents according to the giftedness of their children. We also used bivariate correlations.

Second, we tested the hypotheses of the proposed mediation model. We examined the relationships between observed variables due to the sample size and the number of parameters to be estimated. For this purpose, we used structural equation modelling (SEM) techniques using path analysis and the maximum likelihood (ML) estimation method. We tested a mediation model that included the mediating effect of positive and negative mood on the relationship between EI and SWB. Several mediation models were tested to verify the relationships among variables. Four steps were adopted to analyse the mediation model in the total sample and each sample (sample 1 and sample 2). First, we tested the hypothesised model with SEM in the total sample. Second, we re-specified the hypothesised model in the total sample to improve fit. To reformulate the hypothetical model, we used the information from the modification indices. Third, multi-group SEM was used to test the re-specified model for parents of gifted and unidentified children. Fourth, path analysis was carried out for parents of unidentified children to test the re-specified model. In all tested models, we analysed the direct and indirect effects between the variables [107] and used the bias-corrected (BC) bootstrap confidence interval method [90]. We used a combination of fit indices to check model fit [108]: a) chi-square statistics, normed fit index (NFI), incremental fit index (IFI), comparative fit index (CFI), goodness of fit (GFI), and root mean square residual (RMR). Chi-squared with non-significant values indicates 
good model fit, and the other indices are acceptable if $\geq 0.90$ [109] or $\leq 0.08$ for RMR [110]. However, Newsom [111] affirms that the cut-offs of $\mathrm{Hu}$ and Bentler cannot be applied universally because, for example, the cut-offs can be grouped by sample size [112-116]. In addition, bootstrap analysis was used, and following MacKinnon, Lockwood, Hoffman, West, and Sheet [117], we tested the indirect effects [118,119]. We used Statistical Package for the Social Sciences (SPSS) and Analysis of Moment Structures (AMOS) software version 26.

\section{Results}

\subsection{Descriptive and Correlational Analysis}

Table 1 presents the descriptive analysis (M and SD) and independent $t$-test. Both parent groups reported a high positive mood $(\operatorname{minimum}=1.43$; maximum $=3)$ and less negative $\operatorname{mood}(\operatorname{minimum}=$ 1 ; maximum $=2.92$ ) with no significant difference between the two groups of parents. We analysed negative mood and its components more deeply. We found significant differences between the groups of parents regarding anger. The parents of gifted children felt more anger (minimum $=1$; maximum $=3)$ than the other parents, and their scores on fear $($ minimum $=1$; maximum $=3)$ and sadness (minimum $=1$; maximum $=3$ ) were $\leq 1.5$. Additionally, they reported medium-high scores on SWB (minimum $=1.75$; maximum $=5)$, with no significant difference from parents of unidentified children. The parents of unidentified children reported greater SWB (minimum $=2.17$; maximum $=5$ ). Negative experiences were higher in parents of gifted children (minimum $=1$; maximum $=4.83$ ), with significant differences. Moreover, both parent groups showed medium EI scores $($ minimum $=2.13$; maximum $=$ 4.92). The scores were $<4$ in all dimensions of EI: attention (minimum $=1.63$; maximum $=5$ ), clarity $($ minimum $=1.63$; maximum $=5)$, and repair $($ minimum $=1.88$; maximum $=5)$, with no significant differences between the groups. These results indicate that parents have the skills to feel and express emotions, to understand their emotional states and to regulate them, thereby supporting $\mathrm{H} 1$ and partially supporting $\mathrm{H} 2$. $\mathrm{H} 3$ was not confirmed.

Table 1. Mean, standard deviations, and $t$-test.

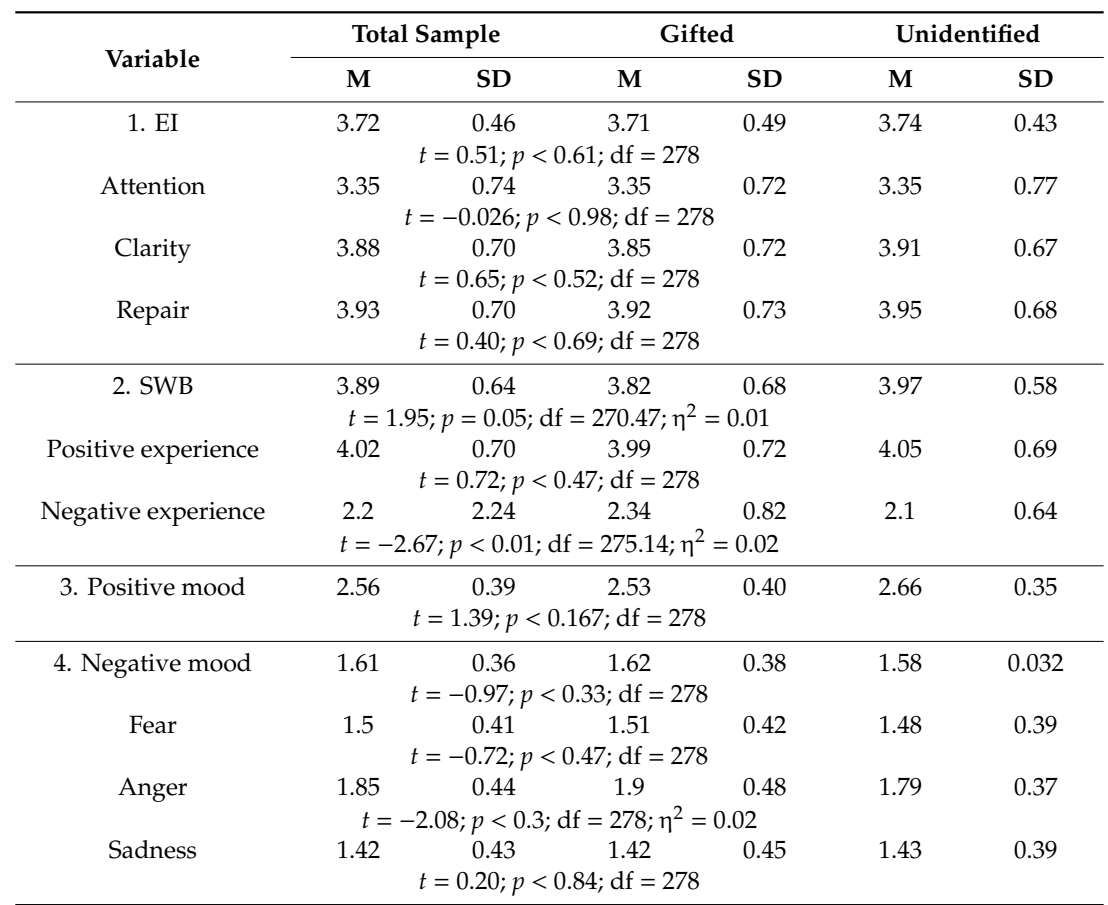

Note: $\mathrm{EI}=\overline{\text { emotional intelligence; } \mathrm{SWB} \text { = subjective well-being; } \mathrm{M}=\text { mean; } \mathrm{SD} \text { = standard deviation; } \mathrm{df}}=$ degree of freedom; $\eta^{2}=$ eta squared. 
Next, correlations among EI, SWB, and mood were analysed. Table 2 shows significantly positive correlations among EI, SWB, and positive mood in the total sample, sample 1, and sample 2. In general, EI correlated with SWB and mood in the total sample and in parents of gifted children. The results showed that EI of parents of unidentified children did not correlate with negative experiences and negative mood. Moreover, attention did not correlate with SWB. EI showed a significant negative correlation with negative experience and negative mood. In parents of unidentified children, negative mood did not correlate with EI.

Table 2. Bivariate correlations in total sample, parents of unidentified children and gifted.

\begin{tabular}{|c|c|c|c|c|c|c|c|c|}
\hline \multicolumn{9}{|c|}{ Total Sample } \\
\hline Variable & SWB & Positive & Negative & $\begin{array}{c}\text { Positive } \\
\text { Mood }\end{array}$ & $\begin{array}{l}\text { Negative } \\
\text { Mood }\end{array}$ & Fear & Anger & Sadness \\
\hline EI & $0.39^{* *}$ & $0.44^{* *}$ & $-0.25^{* *}$ & $0.38^{* *}$ & $-0.20^{* *}$ & $-0.12 *$ & $-0.22 * *$ & $-0.16^{* *}$ \\
\hline Attention & 0.09 & 0.05 & $0.17^{* *}$ & 0.01 & $0.24^{* *}$ & $0.24^{* *}$ & 0.13 * & $0.24 * *$ \\
\hline Clarity & $0.43^{* *}$ & $0.41 * *$ & $-0.34^{* *}$ & $0.34 * *$ & $-0.31^{* *}$ & $-0.25^{* *}$ & $-0.26^{* *}$ & $-0.28 * *$ \\
\hline Repair & $0.46^{* *}$ & $0.46^{* *}$ & $-0.35^{* *}$ & $0.41^{* *}$ & $-0.34 * *$ & $-0.24 * *$ & $-0.33^{* *}$ & $-0.30 * *$ \\
\hline SWB & & & & $0.63^{* *}$ & $-0.66^{* *}$ & $-0.53^{* *}$ & $-0.54^{* *}$ & $-0.55^{* *}$ \\
\hline Positive Experience & - & - & - & $0.60 * *$ & $-0.49 * *$ & $-0.36^{* *}$ & $-0.41 * *$ & $-0.44^{* *}$ \\
\hline Negative Experience & - & - & - & $-0.52 * *$ & $0.66^{* *}$ & $0.57^{* *}$ & $0.53^{* *}$ & $0.53^{* *}$ \\
\hline \multicolumn{9}{|c|}{ Parents of unidentified children } \\
\hline EI & $0.29^{* *}$ & $0.39 * *$ & -0.1 & $0.29 * *$ & -0.61 & -0.04 & -0.07 & -0.04 \\
\hline Attention & -0.17 & -0.03 & $0.26^{* *}$ & 0.01 & $0.32 * *$ & $0.34^{* *}$ & $0.22 * *$ & $0.25^{* *}$ \\
\hline Clarity & $0.34^{* *}$ & $0.36^{* *}$ & $-0.23^{* *}$ & $0.24^{* *}$ & $-0.30 * *$ & $-0.27^{* *}$ & -0.17 & 0.29 ** \\
\hline Repair & $0.40^{* *}$ & $0.42^{* *}$ & $-0.27^{* *}$ & $0.33^{* *}$ & $-0.19^{* *}$ & $-0.19 *$ & $-0.22 *$ & -0.8 \\
\hline SWB & - & - & - & $0.59 * *$ & $-0.60 * *$ & $-0.53^{* *}$ & $-0.42 * *$ & $-0.53 * *$ \\
\hline Positive Experience & - & - & - & $0.57^{* *}$ & $-0.48^{* *}$ & $-0.42 * *$ & $-0.33 * *$ & $-0.41^{* *}$ \\
\hline Negative Experience & - & - & - & $-0.45^{* *}$ & $0.57^{* *}$ & $0.50 * *$ & $0.40^{* *}$ & $0.50^{* *}$ \\
\hline \multicolumn{9}{|c|}{ Parents of gifted children } \\
\hline EI & $0.45^{* *}$ & $0.47^{* *}$ & $-0.34^{* *}$ & $0.43^{* *}$ & $-0.28 * *$ & $-0.16^{* *}$ & $-0.30 * *$ & $-0.23 * *$ \\
\hline Attention & -0.05 & 0.05 & 0.12 & 0.03 & $0.20 *$ & $0.16^{*}$ & 0.09 & $0.24^{* *}$ \\
\hline Clarity & $0.47^{* *}$ & $0.44^{* *}$ & $-0.40 * *$ & $0.40^{* *}$ & $-0.32 * *$ & $-0.23^{* *}$ & $-0.31^{* *}$ & $-0.27^{* *}$ \\
\hline Repair & $0.49^{* *}$ & $0.48^{* *}$ & $-0.40^{* *}$ & $0.46^{* *}$ & $-0.43^{* *}$ & $-0.27^{* *}$ & $-0.39 * *$ & $-0.43^{* *}$ \\
\hline SWB & - & - & - & $0.66^{* *}$ & $-0.69 * *$ & $-0.54^{* *}$ & $-0.60 * *$ & $-0.58^{* *}$ \\
\hline Positive Experience & - & - & - & $0.62 * *$ & $-0.51 *$ & $-0.32 * *$ & $-0.46^{* *}$ & $-0.46^{* *}$ \\
\hline Negative Experience & - & - & - & $-0.55^{* *}$ & $0.71^{* *}$ & $0.62 * *$ & $0.59 * *$ & $0.56^{* *}$ \\
\hline
\end{tabular}

Note: $\mathrm{EI}=$ emotional intelligence; $\mathrm{SWB}=$ subjective well-being; ${ }^{*} p<0.05 ;{ }^{* *} p<0.01$.

\subsection{Test of the Hypothesised Model of Subjective Well-Being, Emotional Intelligence and Mood of Parents}

We performed SEM using the maximum likelihood method to test the hypothesised mediation model. The results of the mediation model for parents revealed a low satisfactory fit to the data (Table 3). According to the hypothesised model, all variables were significantly related. However, the fit index was less than 0.90 and showed a poor fit to the data. Then, the second step was to modify the model following the recommendations of the modification indices.

Table 3. Model fit index for structural equation modelling (SEM) $(n=280)$.

\begin{tabular}{|c|c|c|c|c|c|c|}
\hline Model & $\chi 2 / d f(p)$ & NFI & IFI & CFI & GFI & RMR \\
\hline Total sample of parents & $68.79 / 1(\leq 0.001)$ & 0.81 & 0.81 & 0.81 & 0.90 & 0.03 \\
\hline Re-specified model & $20.08 / 1(\leq 0.001)$ & 0.94 & 0.95 & 0.95 & 0.97 & 0.01 \\
\hline Multigroup & $19.43 / 2(\leq 0.001)$ & 0.95 & 0.95 & 0.95 & 0.94 & 0.01 \\
\hline Parents of gifted students re-specified model & $12.39 / 1(\leq 0.001)$ & 0.95 & 0.95 & 0.95 & 0.96 & 0.01 \\
\hline Unidentified Students re-specified & $7.48 / 2(0.02)$ & 0.93 & 0.95 & 0.95 & 0.97 & 0.01 \\
\hline
\end{tabular}

Note: $\chi 2$ = chi-squared; d.f. = degrees of freedom; NFI = normed fit index; IFI = incremental fit index; and CFI = comparative fit index; GFI = Goodness of Fit; RMR = Root Mean Square Residual.

According to the results of SEM of the re-specified model in Table 3, this mediation model is supported. Figure 2 illustrates the non-standardised coefficients of the mediation model and their 
significance in the total sample of parents. This figure reveals that the path was significant. Then, we used the re-specified model to design and test the optimal model. Thus, H5 was supported.

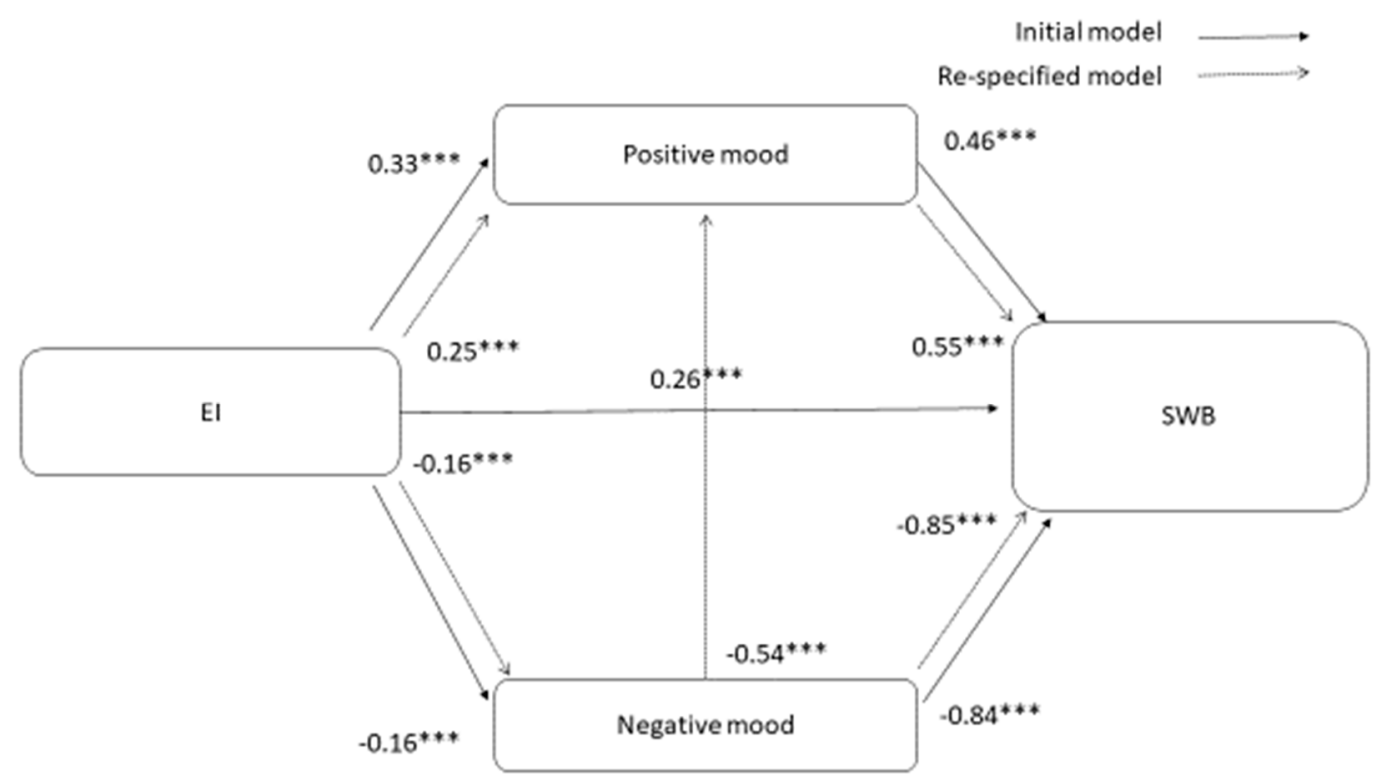

Figure 2. Non-standardised coefficients of the hypothetical and re-specified models and significance.

Note: ${ }^{* * *} p<0.001,{ }^{* *} p<0.01,{ }^{*} p<0.05$.

Next, we used multigroup SEM to analyse the differences in the re-specified model according to the giftedness of the children. The results showed satisfactory outcomes (Table 3) and non-standardised coefficient estimates (Figure 3).

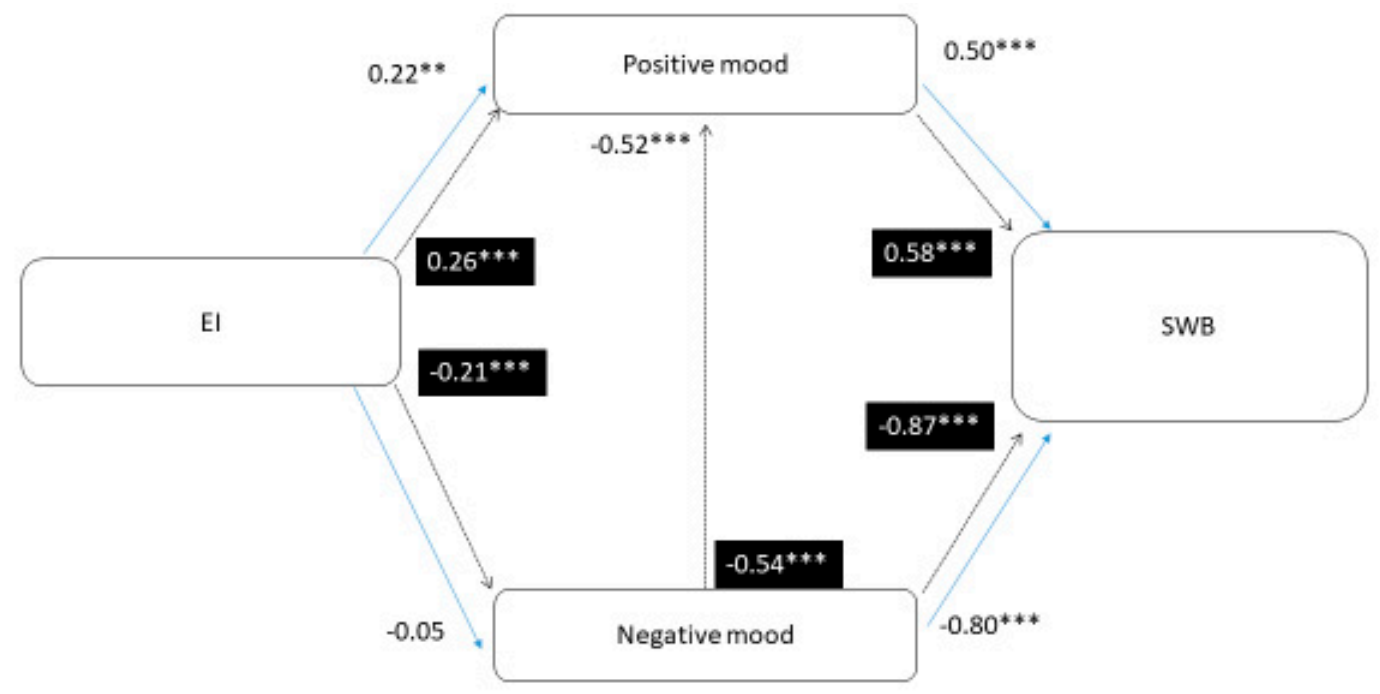

Figure 3. Non-standardised coefficients of multigroup analysis. Note: ${ }^{* * *} p<0.001,{ }^{* *} p<0.01,{ }^{*} p<0.05$. The black box shows the scores of the parents of gifted children.

The results for the parents of unidentified students in Figure 3 shows that the path from EI to negative mood was insignificant. For parents of gifted children, this path was significant. Thus, we generated a final model [120] for parents of unidentified students (Figure 4). In this new model, we eliminated the non-significant path. The new model of parents of unidentified children had acceptable fit (see Table 3). Table 4 shows the standardised coefficients, and the results showed that direct and indirect effects were statistically significant. H6 was supported. 


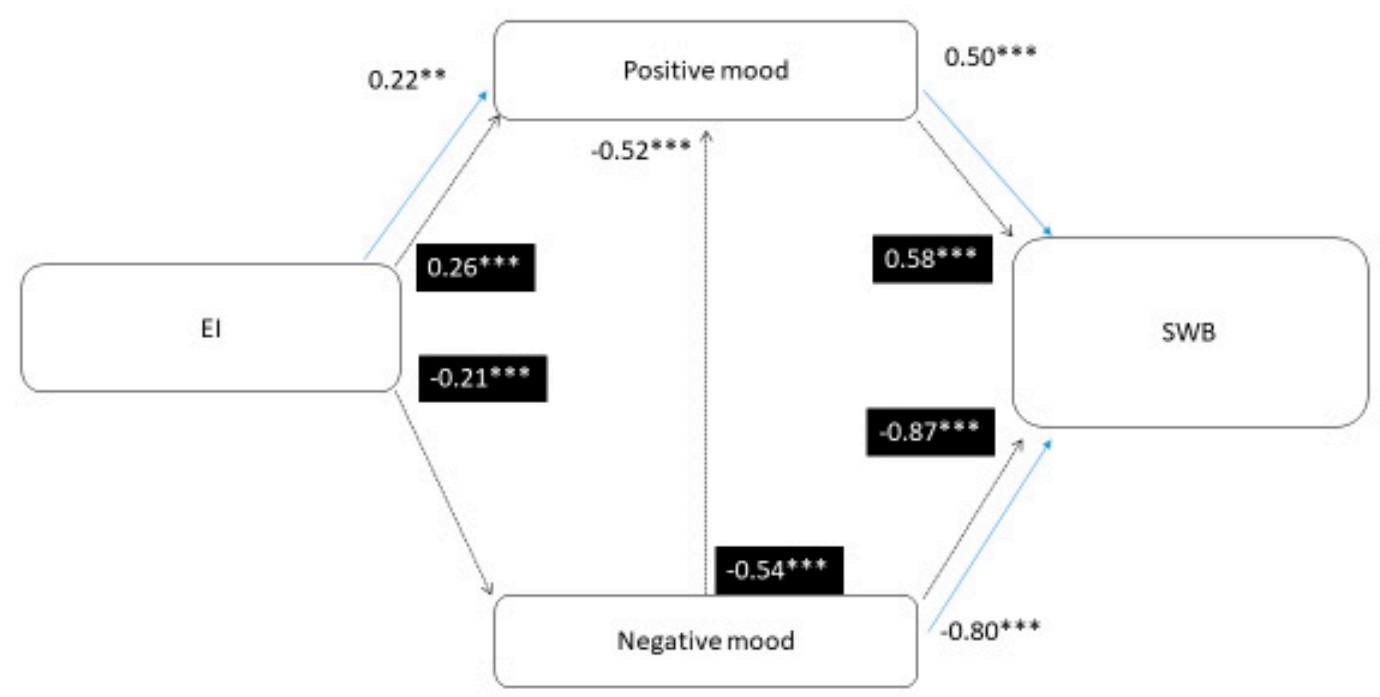

Figure 4. Non-standardised coefficients of the final model for the two samples. Note: ${ }^{* * *} p<0.001$, ** $p<0.01,{ }^{*} p<0.05$. The black box shows the scores of the parents of gifted children.

Table 4. Results of the mediation model with Standardised SEM effects.

\begin{tabular}{ccccccc}
\hline & \multicolumn{2}{c}{ Total Sample } & \multicolumn{3}{c}{ Multigroup Analysis } \\
\hline & & & Gifted Students & Unidentified Students \\
\hline & $\beta$ & $p$-Value & $\beta$ & $p$-Value & $\beta$ & $p$-Value \\
\hline EI on negative mood & -0.16 & 0.003 & -0.21 & 0.003 & & \\
EI on positive mood & 0.25 & 0.001 & 0.26 & 0.001 & 0.22 & 0.007 \\
negative on positive mood & -0.54 & 0.001 & -0.54 & 0.001 & -0.52 & 0.001 \\
Positive mood on SWB & 0.55 & 0.001 & 0.58 & 0.001 & 0.50 & 0.001 \\
Negative mood on SWB & -0.85 & 0.001 & -0.87 & 0.001 & -0.80 & 0.001 \\
\hline
\end{tabular}

Note: $\mathrm{EI}=$ emotional intelligence; $\mathrm{SWB}=$ subjective well-being.

In the re-specified model of parents in the total sample, direct and indirect effects were statistically significant. There were direct effects of EI on negative $\operatorname{mood}(\mathrm{Coeff}=-0.16, \mathrm{SE}=0.05, p$-value $=$ 0.003 ), EI on positive mood (Coeff $=0.25, \mathrm{SE}=0.05, p$-value $=0.001)$, and negative on positive mood $($ Coeff $=-0.54, \mathrm{SE}=0.06, p$-value $=0.001)$. Moreover, the direct effects of positive mood (Coeff $=$ $0.55, \mathrm{SE}=0.07, p$-value $=0.001)$ and negative $\operatorname{mood}(\mathrm{Coeff}=-0.85, \mathrm{SE}=0.08, p$-value $=0.001)$ were also statistically significant. The indirect effects were all statistically significant, including EI on SWB through negative $\operatorname{mood}($ Coeff $=0.32, p$-value $=0.003,95 \%$ BC confidence interval $=0.20$ to 0.49 ) and positive $\operatorname{mood}($ Coeff $=0.08, p$-value $=0.001,95 \%$ BC confidence interval $=0.03$ to 0.15$)$ and negative mood on SWB through positive $\operatorname{mood}($ Coeff $=-0.30, p$-value $=0.001,95 \%$ BC confidence interval $=$ -0.43 to -0.20 ). The confidence intervals of all variables did not include 0 ; thus, the mediation effects were statistically significant.

The re-specified model of parents of gifted children showed that the direct and indirect effects were statistically significant. The direct effects were EI on negative $\operatorname{mood}(\mathrm{Coeff}=-0.21, \mathrm{SE}=0.05$, $p$-value $=0.003)$, EI on positive $\operatorname{mood}($ Coeff $=0.26, \mathrm{SE}=0.05, p$-value $=0.001)$, and negative on positive mood (Coeff $=-0.54, \mathrm{SE}=0.07, p$-value $=0.001)$. Moreover, the direct effects of positive $\operatorname{mood}($ Coeff $=0.58, \mathrm{SE}=0.09, p$-value $=0.001)$ and negative $\operatorname{mood}($ Coeff $=-0.87, \mathrm{SE}=0.10, p$-value $=$ 0.001) were statistically significant. The indirect effects were all statistically significant, including EI on SWB through negative mood (Coeff $=0.40, p$-value $=0.003,95 \%$ BC confidence interval $=0.22$ to 0.57 ) and positive $\operatorname{mood}($ Coeff $=0.12, p$-value $=0.01,95 \%$ BC confidence interval $=0.05$ to 0.20 ) and negative mood on SWB through positive $\operatorname{mood}($ Coeff $=-0.31, p$-value $=0.001,95 \%$ BC confidence 
interval $=-0.47$ to -0.19 ). The confidence intervals did not include 0 , and the mediation effects were statistically significant.

In the final model of parents of unidentified students, the direct and indirect effects were statistically significant. The direct effects were EI on positive $\operatorname{mood}($ Coeff $=0.22, \mathrm{SE}=0.08, p$-value $=0.007)$ and negative on positive mood (Coeff $=-0.52, \mathrm{SE}=0.11, p$-value $=0.001)$. Moreover, the direct effects of positive $\operatorname{mood}($ Coeff $=0.50, \mathrm{SE}=0.10, p$-value $=0.001)$ and negative $\operatorname{mood}($ Coeff $=-0.80, \mathrm{SE}=0.13$, $p$-value $=0.001)$ were statistically significant. The indirect effects were all statistically significant, including EI on SWB through positive mood (Coeff $=0.11, p$-value $=0.03,95 \%$ BC confidence interval $=0.03$ to 0.20 ) and negative mood on SWB through positive $\operatorname{mood}($ Coeff $=-0.26 p$-value $=0.01,95 \%$ $\mathrm{BC}$ confidence interval $=-0.47$ to -0.14 ). The mediation effects were statistically significant with confidence intervals that did not include 0 .

These results showed that $\mathrm{H} 4$ is acceptable. EI predicts SWB mediated by mood (H5). Positive and negative moods mediate the relationship between EI and SWB in parents of gifted children, but negative mood does not mediate the relationship between EI and SWB in parents of unidentified children (H6).

\section{Discussion}

SWB is fundamental for maintaining the health of people of all ages [121]. Family is one of the social contexts that strongly influences SWB [17]. The well-being of parents may be a protective factor because it may help to reduce the negative effects of situations children may have to endure. Conversely, a lesser state of well-being in parents may become a risk factor for their children and their development; that is, the relationship is bi-directional. The well-being of parents may diminish when children present intellectual giftedness $[6,7,9]$. On the other hand, individuals identified as gifted seem to be characterised as having more difficulties in their lives and appear to come from families with more problems. In this study, we focus on the SWB, EI, and mood of parents following the model proposed by Casino-García et al. [10]. In addition, we have analysed the differences between parents of gifted children and those of unidentified children.

Our results demonstrate that, in general, parents have average levels of well-being; receive medium-high scores in PA, and show a high positive mood. However, comparing the two groups reveals that the affective balance of SWB is significantly lower among parents of gifted children. Specifically, significant differences in NA are found. Parents of children identified as gifted have significantly more negative experiences and, therefore, have lower SWB [62]. Regarding moods, in general, no significant differences were found between the two groups. However, in analysing negative moods in more detail, differences were found regarding the levels of anger (significantly higher in parents of gifted children). Thus, we can confirm H1 and partially confirm H2.

The effects of family are similar to those found by McDowall, Rimlinger, and Free $[6,7,9]$. They can be explained by the relationship between the difficulties and conflicting experiences of children and the emotional system of parents [32]. Children and adolescents who are gifted may feel more sadness [10]. The major anger of parents can be associated with their children's melancholy, particularly when their sadness is justified. It is often difficult to differentiate negative emotions directed at their child or others. Factors such as stress can also influence the emotions of the sample of parents [69]. Moreover, a high score was observed for the involvement of gifted students in bullying cases, particularly for victimisation, and this score was higher than that of the school population in general. Twenty-five percent of those affected by bullying believe that their teachers had, in some way, facilitated their becoming victims of bullying or cyberbullying [48]. In a clinical setting, the level of anger in parents is associated with a lack of satisfaction with service access and with health workers as well as with the perceived severity of the child's health status [122]. Parents of these students may have the same motives within the educational field due to the lack of a satisfactory educational response [52,60], the lack of teacher training for professionals in education in this specific area [61], and the seriousness of the consequences for many students, which include serious psychological 
effects related to cyber-victimisation, greater depression, more anxiety, more stress, less social support, and worse quality of life for victims of harassment and cyberbullying [48].

In our study, we reject H3, as our results demonstrate no differences in EI between the two groups in any of its dimensions (attention, clarity, and repair). Although the scores of parents of children with intellectual giftedness in repair and clarity (particularly this last dimension) are slightly lower, they are not significantly different and, in general, are medium-high. This factor could also explain why the levels of well-being of these families, despite the greater number of negative experiences, are average. Personal resources can protect parents from parental stress [58], and EI has a positive impact on their control [88]. Belonging to the association, receiving relevant information, and sharing experiences with other parents may help them develop the necessary emotional competencies for raising gifted children [23].

Referring to the relationship model, the results allowed the acceptance of H4: EI predicts SWB. The findings of studies such as Sánchez-Álvarez, Extremera, and Fernández-Berrocal [81] support our results. Specifically, we found that, when a parent has high levels of EI, they have high SWB. However, the relationship between EI and SWB is not simple. We replicated the model proposed by Casino-García et al. [10], but our data led us to re-specify the model by eliminating the direct relationship between EI and SWB and adding the influence of negative mood on positive mood. Our results also confirm the mediation proposed in H5. However, such mediation is different in the group of parents of gifted children than in the group of parents of unidentified children $(\mathrm{H} 6)$. Among parents of unidentified children, positive mood mediation exists between EI and SWB and between negative mood and SWB. Among parents of gifted children, full mediation by negative and positive mood exists between EI and SWB. Our results are in line with those of Casino-García et al. [10]; the relationship between EI and SWB is mediated by positive mood in unidentified children. In identified children, the influence of EI is mediated by both positive and negative mood. However, a more concerning effect is observed in parents, as negative mood influences positive mood.

The results of this study confirm that being a parent is associated with greater emotional ups and downs. Children bring many joys, but parents experience higher levels of stress, worry, and anger than non-parents [56]. In this sense, parenting a student with high abilities places the student in a vulnerable group because some gifted students are over-excited [45]. When children have a difficult or more sensitive temperament, parents experience relatively low levels of well-being [44]. This generates an emotional reaction from parents. Additionally, temperament has a strong genetic component, and parents and children may be more sensitive to affection and experience greater mediation in their well-being.

\subsection{Theoretical and Practical Implications}

Our study makes several contributions to the literature. First, we aimed to advance the understanding of parents and, specifically, the SWB of parents of gifted children by exploring the influence of EI and mood (as recommended in [44]). We focused on this process because most research has been directed towards the influence of parental characteristics on children. Family is the first educational area, the most relevant, and the first school of emotional literacy for the child. At home, children learn, through the words and actions of their parents and available role models, to express themselves, how others respond to their feelings, to think about their feelings, to think about the possible responses, and how to interpret and express their desires and fears [123]. A child must have role models to advance optimally in their socialisation [70]. Emotions and their regulation are learned since childhood and are influenced by the closer context, with family and school playing major roles [70]. Therefore, parents can be a protective factor or a risk factor.

Moreover, our study extends research on the affective component of the link between EI and SWB, as suggested by other authors [81]. Mediators with positive and negative effects have been suggested in the scientific literature [44]; in this investigation, the parents of gifted children and unidentified children were tested. We expand on the previous literature considering the SWB of adults by including 
the parental roles of those with gifted children. We analysed the SWB, EI, and mood of parents of gifted children because they could be considered a vulnerable group. Third, scant literature is available on families with gifted students [8], and we contribute new information to a field that has barely been studied.

Our study has various practical consequences and can be used by both educational professionals and public health workers. First, this study will be useful for psychologists, therapists, and various other professionals who manage the physical and psychological health of children, adolescents, and young people with intellectual giftedness and of their parents in developing a family-centred approach. The variables analysed in this study not only affect the child [124] but also the family environment, partner relationships, extended family relationships, and other social relationships [32]. Additionally, the variables are related to situations of negative stress (distress) and generate health problems for parents [125]. This study is also useful for business entrepreneurs because SWB, EI, and the mood of parents may affect their work, efficiency, and relationships in the workplace [126].

Second, parents' well-being is affected [4] by actions centred on the family [55] that value their well-being and needs. Emotional competences and abilities for well-being can be taught [19]. A high level of SWB could play a protective role against victimisation [127]. Evaluative techniques and the detection of intellectual giftedness must be designed and focus on basic competences that are necessary for the task of being a parent, who, without doubt, will contribute to the quality of the gifted students' processes of attention, thereby favouring their comprehensive development as students and people [128].

Third, educational centres can consider family needs in identification and adaptation to the educational system to guarantee a holistic approach to each student [128]. Closer cooperation between family and school [23] can be encouraged by designing schools and parental programmes that allow their empowerment [24], given paternal expectations regarding the importance of academic achievement [129], as well as workshops on parental guidance of the academic adjustment of adolescents [74]. Some authors suggest that classes for parents should start when children are identified, in addition to providing resources, access to professionals and contact with other parents to share experiences and concerns. Emotional education programmes for parents must be implemented to enable more effective intervention in the family framework with positive effects on the personal development of their children [70]. Counsellors can help families develop problem-solving and coping abilities [55]. It is important to learn more about parents' perceptions because they can have a mutual influence on the efficacy of the educational response that students receive at schools. Parental support can be a decisive factor in interventions for gifted students [30]. The contexts must be clear; intervention within high capacities must consider the influencing factors in the daily life of the subject, particularly regarding family education and parental competences, in order to contribute to their well-being [128].

\subsection{Limitations and Future Research}

Our study possesses limitations. First, we used a convenience sample. In Spain, few students are identified with intellectual giftedness [130]; thus, being identified sets the child apart as different. In our study, we mainly enrolled parents belonging to parents' associations. It is possible that many parents attend these associations to resolve problems and for the support of other parents and specialists. Etikan et al. [99] claimed that convenience sampling is a commonly used method in this type of investigation and has been very useful. However, our sample may have biases inherent to any clinical sample and may not be representative of the studied population. Initially, problems can be more severe or complex [131], but they also receive more attention. Hence, future investigations should expand the sample to parents of gifted students that do not belong to associations.

Second, this study was performed using self-report measures, which can cause common error bias. In this paper, the scales had different formats and anchor points [100]. Thus, future studies should use quantitative and qualitative methods. 
Third, some concepts that our study analysed (e.g., SWB) are susceptible to social desirability bias (SDB) (e.g., [132]). SDB is one of the most important sources of bias [133], and many questions exist regarding how to detect and measure SDB. The literature suggests that self-reporting is an important method of data collection [134]. Our study reduced social desirability response bias by assuring complete anonymity. Future studies should mitigate this source of bias-for example, by using social desirability scales [135] or contrasting anonymous and non-anonymous questionnaires [136].

Fourth, SWB has a multi-causal nature. Azizan and Mahmud [137] highlighted the links of SWB with personality, health, family life, work experiences, cognitive processes, emotion regulation, etc. However, the authors showed that the findings are inconsistent [138]. In this paper, we chose parents with/without children identified as gifted as the variable. Future research should examine other relevant topics in parenthood, such as physical or psychological problems.

Despite these limitations and because of the lack of studies available on the well-being of families of students with high capacities, we believe our study can aid the development of a preliminary diagnosis of the well-being of these students and their family environments. Based on the results, it would be interesting to verify, as claimed by Umberson et al. [58], how social resources influence well-being levels.

\section{Conclusions}

We aimed to determine SWB, EI, and mood and test a model of the mediating role of mood in the relationship between the EI and SWB of parents of gifted and unidentified children. In this investigation, we highlight that parents of children identified as gifted showed lower levels of SWB perceived more negative experiences and felt more anger than parents of unidentified children and adolescents. However, the two groups had similar EI scores. Mood was also identified as a mediator in the relationship between EI and SWB. Our study showed that positive and negative mood mediated this relationship in parents in general. That said, the influence of EI on SWB in parents of gifted children was mediated by both negative and positive mood, while only positive mood mediated this relationship in parents of unidentified children. These results show the importance of relying on the families of these students to detect barriers and identify needs and of evaluating well-being and developing programmes of prevention and attention focused on the family to guarantee the equity, inclusion, and emotional accessibility of these students. Moreover, it is necessary to increase the training of health and educational professionals so that they can assess the emotional needs of parents of gifted children, contribute to their empowerment, develop preventive interventions and, if necessary, develop therapies.

Author Contributions: L.I.L.-I. participated in the design of the study, analysed the data, collaborated on the interpretation of the results, and collaboratively wrote the manuscript. A.M.C.-G. participated in the design of the study, analysed the data, collaborated on the interpretation of the results, and collaboratively wrote the manuscript. J.G.-P. participated in the design of the study, analysed the data, and collaborated on the interpretation of the results. All authors have read and agreed to the published version of the manuscript.

Funding: The Catholic University of Valencia "San Vicente Mártir" (Valencia, Spain) and Fundació "Prevere Bernat Beny" (Comunitat Valenciana) contributed to the funding of this project.

Acknowledgments: ACAST (Castellón) and AVAST (Valencia) are Valencian associations for gifted and talented families. Both have selflessly participated in the study.

Conflicts of Interest: The authors declare no conflict of interest.

\section{References}

1. Colangelo, N.; Dettmann, D.F. A review of research on parents and families of gifted children. Except. Child. 1983, 50, 20-27. [CrossRef]

2. Guzmán, K.; Bastidas, B.; Mendoza, M. Estudio del rol de los padres de familia en la vida emocional de los hijos. Apunt. Univ. 2019, 9, 61-72. 
3. Bagnato, M.J. El bienestar emocional en madres de hijos con diagnóstico de TEA. Rev. De Psicol. Terc. Época 2019, 18, 46-60. [CrossRef]

4. Martin-Krumm, C.; Fenouillet, F.; Csillik, A.; Kern, L.; Besancon, M.; Heutte, J.; Paquet, Y.; Delas, Y.; Trousselard, M.; Lecorre, B.; et al. Changes in Emotions from Childhood to Young Adulthood. Child Indic. Res. 2018, 11, 541-561. [CrossRef]

5. Zeidner, M. "Don't worry-Be happy": The sad state of happiness research in gifted students. High Abil. Stud. 2020, 1-18. [CrossRef]

6. McDowall, J. Exploring the Experiences of New Zealand Mothers Raising Intellectually Gifted Children: Maternal Strains, Resources, and Coping Behaviours. Master's Thesis, University of Canterbury, Christchurch, New Zealand, 2019.

7. Rimlinger, N.A. Dwelling on the Right Side of the Curve: An Exploration of the Psychological Wellbeing of Parents of Gifted Children. Ph.D. Thesis, The Australian National University, Canberra ACT, Australia, March 2016.

8. Renati, R.; Bonfilgilio, N.S.; Pfeiffer, S. Challenges raising a gifted child: Stress and resilience factors within the family. Gift. Educ. Int. 2017, 33, 145-162. [CrossRef]

9. Free, S.A. Group support for parents of gifted children in the western region of Melbourne, Australia. In Giftedness and Talent; Ballam, N., Moltzen, R., Eds.; Springer: Singapore, 2017; pp. 75-95.

10. Casino-García, A.M.; García-Pérez, J.; Llinares-Insa, L.I. Subjective Emotional Well-Being, Emotional Intelligence, and Mood of Gifted vs. Unidentified Students: A Relationship Model. Int. J. Environ. Res. Public Health 2019, 16, 3266.

11. Zeidner, M. Tentative guidelines for the development of an ability-based emotional intelligence intervention program for gifted students. High Abil. Stud. 2017, 28, 29-41. [CrossRef]

12. Ysern, L. Relación Entre la Inteligencia Emocional, Recursos y Problemas Psicológicos, en la Infancia y Adolescencia. Ph.D. Thesis, Universitat de València, Valencia, Spain, July 2016.

13. Schutte, N.S.; Malouff, J.M.; Simunek, M.; McKenley, J.; Hollander, S. Characteristic emotional intelligence and emotional well-being. Cogn. Emot. 2002, 16, 769-785. [CrossRef]

14. Zeidner, M.; Shani-Zinovich, I.; Matthews, G.; Roberts, R.D. Assessing emotional intelligence in gifted and nongifted high school students: Outcomes depend on the measure. Intelligence 2005, 33, 369-391. [CrossRef]

15. Al-Hamdan, N.S.; Al-Jasim, F.A.; Abdulla, A.M. Assessing the Emotional Intelligence of Gifted and Talented Adolescent Students in the Kingdom of Bahrain. Roeper Rev. 2017, 39, 132-142. [CrossRef]

16. Pollet, E.; Schnell, T. Brilliant: But What For? Meaning and Subjective Well-Being in the Lives of Intellectually Gifted and Academically High-Achieving Adults. J. Happiness Stud. 2017, 18, 1459-1484. [CrossRef]

17. Velasco, M.F.; Quiroga-Garza, A. Factores sistémicos asociados a la experiencia escolar de adolescentes con alto potencial intelectual. Rev. Mex. Investig. Educ. 2018, 23, 1051-1074.

18. Zeidner, M. Emotional Intelligence (EI) and the Gifted. In Handbook of Giftedness in Children: Psychoeducational Theory, Research, and Best Practices, 2nd ed.; Pfeiffer, S., Ed.; Springer: Tallahassee, FL, USA, 2018; pp. 101-114.

19. Pérez-Escoda, N.; Filella, G.; Alegre, A.; Bisquerra, R. Desarrollo de la competencia emocional de maestros y alumnos en contextos escolares. Electron. J. Res. Educ. Psychol. 2012, 10, 1183-1208. [CrossRef]

20. Morris, A.; Silk, J.; Stenberg, L.; Myers, S.; Robinson, L. The Role of the family context in the development of emotion regulation. Soc. Dev. 2007, 16, 362-388. [CrossRef]

21. Cumberland-Li, A.; Eisenberg, N.; Champion, C.; Gershoff, E.; Fabes, R.A. The relation of parental emotionality and related dispositional traits to parental expression of emotion and children's social functioning. Motiv. Emot. 2003, 27, 27-56. [CrossRef]

22. Sánchez-Núñez, M.T.; Fernández-Berrocal, P.; Latorre, J.M. Assessment of emotional intelligence in the family: Influences between parents and children on their own perception and that of others. Fam. J. 2013, 21, 65-73. [CrossRef]

23. Robinson, A.; Shore, B.M.; Enersen, D.L. Best Practices in Gifted Education. An Evidence-Based Guide; Prufrock Press: Waco, TX, USA, 2007; pp. 7-13.

24. Saranli, A.G.; Metin, E.N. The Effects of the SENG parent education model on parents and gifted children. Sci. Educ. 2014, 39, 1-13. [CrossRef]

25. Ohannessian, C.M.; Lerner, R.M.; Lerner, J.V.; von Eye, A. Discrepancies in adolescents' and parents' perceptions of family functioning and adolescent emotional adjustment. J. Early Adolesc. 1995, 15, 490-516. [CrossRef] 
26. Olszewski-Kubilius, P.; Lee, S.Y.; Thomson, D. Family environment and social development in gifted students. Gift. Child Q. 2014, 58, 199-216. [CrossRef]

27. Ben-Artzey, N. The gifted child as an equal partner or minority in the sibling relationship: The parents' perspective. Child Indic. Res. 2019, 12, 2151-2171. [CrossRef]

28. Sallés, C.; Ger, S. Las competencias parentales en la familia contemporánea: Descripción, promoción y evaluación. Educ. Social. Rev. Interv. Socioeducativa 2011, 49, 25-47.

29. Freeman, J. Por qué algunos niños con altas capacidades son notablemente más exitosos en la vida que otros con iguales oportunidades y habilidad. Rev. Educ. 2015, 368, 255-278.

30. Jolly, J.L.; Matthews, M.S.; Nester, J. Homeschooling the gifted: A parent's perspective. Gift. Child Q. 2013, 57, 121-134. [CrossRef]

31. Villanueva, L.; Górriz, A.B.; Prado-Gascó, V.; González, R. The role of emotion awareness and mood: Somatic complaints and social adjustment in late childhood. Psychol. Health Med. 2015, 20, 419-430. [CrossRef] [PubMed]

32. Musitu, G.; Callejas, J.E. El modelo de estrés familiar en la adolescencia: MEFAD. Int. J. Dev. Educ. Psychol. 2017, 1, 11-19. [CrossRef]

33. Diener, E.; Lucas, R.E.; Oishi, S. Advances and Open Questions in the Science of Subjective Well-Being. Collabra Psychol. 2018, 4, 15. [CrossRef]

34. Santander, S.; Zubarew, T.; Santelices, L.; Argollo, P.; Cerda, J.; Bórquez, M. Influencia de la familia como factor protector de conductas de riesgo en escolares chilenos. Rev. Med. Chile 2008, 136, 317-324. [CrossRef]

35. Montero, L.; Gewerc, A. La profesión docente en la sociedad del conocimiento. Una mirada a través de la revisión de investigaciones de los últimos 10 años. Rev. Educ. A Distancia 2018, 56, 3. [CrossRef]

36. Gagné, F. De los genes al talento: La perspectiva DMGT/CMTD. Revisita Educ. 2015, 368, 12-39.

37. Diener, E. Subjective Well-Being. Psychol. Bull. 1984, 95, 542-575. [CrossRef] [PubMed]

38. Arthaud-Day, M.L.; Rode, J.C.; Mooney, C.H.; Near, J.P. The subjective well-being construct: A test of its convergent, discriminant, and factorial validity. Soc. Indic. Res. 2005, 74, 445-476. [CrossRef]

39. Diener, E.; Wirtz, D.; Biswas-Diener, R.; Tov, W.; Kim-Prieto, C.; Choi, D.W.; Oishi, S. New measures of well-being. In Assessing Well-Being; Diener, E., Ed.; Springer: Dordrecht, The Netherlands, 2009; pp. 247-266.

40. Larsen, R. The contributions of positive and negative affect to emotional well-being. Psychol. Top. 2009, 18, 247-266.

41. Li, F.; Bai, X.; Wang, Y. The Scale of Positive and Negative Experience (SPANE): Psychometric Properties and Normative Data in a Large Chinese Sample. PLoS ONE 2013, 8, e61137. [CrossRef] [PubMed]

42. Herbst, C.M.; Ifcher, J. The increasing happiness of US parents. Rev. Econ. Househ. 2016, 14, 529-551. [CrossRef]

43. Becker, C.; Kirchmaier, I.; Trautmann, S.T. Marriage, parenthood and social network: Subjective well-being and mental health in old age. PLoS ONE 2019, 14, e0218704. [CrossRef] [PubMed]

44. Nelson, S.K.; Kushlev, K.; Lyubomirsky, S. The pains and pleasures of parenting: When, why, and how is parenthood associated with more or less well-being? Psychol. Bull. 2014, 140, 846. [CrossRef] [PubMed]

45. Alias, A.; Rahman, S.; Abd Majid, R.; Yassin, S.F.M. Dabrowski's overexcitabilities profile among gifted students. Asian Soc. Sci 2013, 9, 120. [CrossRef]

46. Beckmann, E.; Minnaert, A. Non-cognitive Characteristics of Gifted Students with Learning Disabilities: An In-depth Systematic Review. Front. Psychol. 2018, 9, 504. [CrossRef]

47. Allen, W.T. Bullying and the Unique Socioemotional Needs of Gifted and Talented Early Adolescents: Veteran Teacher Perspectives and Practices. Roeper Rev. 2017, 39, 269-283. [CrossRef]

48. González-Cabrera, J. Informe Ejecutivo del Proyecto Ciberaacc. Acoso y Ciberacoso en Estudiantes de Altas Capacidades: Prevalencia Y Afectación Psicológica; UNIR: Logroño, Spain, 2018; pp. 22-33.

49. González-Cabrera, J.; Tourón, J.; Machimbarrena, J.M.; Gutiérrez-Ortega, M.; Álvarez-Bardón, A.; Garaigordobil, M. Cyberbullying in Gifted Students: Prevalence and Psychological Well-Being in a Spanish Sample. Int. J. Environ. Res. Public Health 2019, 16, 2173. [CrossRef] [PubMed]

50. MacFarlane, B.; Mina, K. Cyberbullying and the gifted: Considerations for social and emotional development. Gift. Child Q. 2018, 41, 130-135. [CrossRef]

51. Gubbels, J.; Segers, E.; Verhoeven, L. Cognitive, socioemotional, and attitudinal effects of a triarchic enrichment program for gifted children. J. Educ. Gift. 2014, 37, 378-397. [CrossRef]

52. Martín, R.M.; Vargas, M. Altas capacidades en la escuela inclusiva. J. Parents Teach. 2014, 358, $39-44$. 
53. Garn, A.C.; Matthews, M.S.; Jolly, J.L. Parental influences on the academic motivation of gifted students: A self-determination theory perspective. Gift. Child Q. 2010, 54, 263-272. [CrossRef]

54. Olszewski-Kubilius, P. The role of the family in talent development. In Handbook of Giftedness in Children: Psychoeducational Theory, Research, and Best Practices, 2nd ed.; Pfeiffer, S., Ed.; Springer: Tallahassee, FL, USA, 2018; pp. 53-70.

55. King, G.; King, S.; Rosenbaum, P.; Goffin, R. Family-centered caregiving and well-being of parents of children with disabilities: Linking process with outcome. J. Pediatr. Psychol. 1999, 24, 41-53. [CrossRef]

56. Deaton, A.; Stone, A.A. Evaluative and hedonic wellbeing among those with and without children at home. Proc. Natl. Acad. Sci. USA 2014, 111, 1328-1333. [CrossRef]

57. Nelson, S.K.; Kushlev, K.; English, T.; Dunn, E.W.; Lyubomirsky, S. In defense of parenthood: Children are associated with more joy than misery. Psychol. Sci. 2013, 24, 3-10. [CrossRef] [PubMed]

58. Umberson, D.; Pudrovska, T.; Reczek, C. Parenthood, childlessness, and well-being: A life course perspective. J. Marriage Fam. 2010, 72, 612-629. [CrossRef]

59. Vialle, W.; Heaven, P.C.L.; Ciarrochi, J. On Being Gifted, but Sad and Misunderstood: Social, emotional, and academic outcomes of gifted students in the Wollongong Youth Study. Educ. Res. Eval. 2007, 13, 569-586. [CrossRef]

60. Tourón, J. Las Altas Capacidades en el sistema educativo español: Reflexiones sobre el concepto y la identificación. Rev. Investig. Educ. 2020, 38, 15-32. [CrossRef]

61. López, E.; Martín, M.I.; Palomares, A. Empoderamiento docente en el ámbito d elas altas capacidades intelectuales. Mitos y creencias en los docentes de Educación Primaria. Contextos Educ. 2019, 24, $63-76$.

62. Busseri, M.A.; Sadava, S.W. A review of the tripartite structure of subjective well-being: Implications for conceptualization, operationalization, analysis, and synthesis. Pers. Soc. Psychol. Bull. 2011, 15, 290-314. [CrossRef] [PubMed]

63. Rieffe, C.; Meerum-Terwogt, M.; Bosch, J. Emotion understanding in children with frequent somatic complaints. Eur. J. Dev. Psychol. 2004, 1,31-47. [CrossRef]

64. Scherer, K. What are emotions? And how can they be measured? Soc. Sci. Inf. 2005, 44, 695-729. [CrossRef]

65. Górriz, A.B.; Prado-Gascó, V.; Villanueva, L.; Ordóñez, A.; González, R. The MOOD questionnaire: Adaptation and validation of the Spanish version. Psicothema 2013, 25, 252-257.

66. Salovey, P.; Mayer, J.D. Emotional intelligence. Imagin. Cogn. Personal. 1990, 9, 185-211. [CrossRef]

67. Mayer, J.D.; Salovey, P. What is emotional intelligence? In Emotional Development and Emotional Intelligence: Educational Implications; Sluyter, D.J., Ed.; Basic Books: New York, NY, USA, 1997; pp. 3-34.

68. Mayer, J.D.; Salovey, P.; Caruso, D.R.; Sitarenios, G. Emotional intelligence as a standard intelligence. Emoción 2001, 1, 232-242. [CrossRef]

69. Eisenberg, N.; Cumberland, A.; Spinrad, T.L. Parental socialization of emotion. Psychol. Inq. 1998, 9, $241-273$. [CrossRef]

70. Ramírez-Lucas, A.; Ferrando, M.; Sáinz, M. ¿Influyen los estilos parentales y la Inteligencia Emocional de los padres en el desarrollo emocional de sus hijos escolarizados en $2^{\circ}$ ciclo de educación infantil? Acción Psicol. 2015, 12, 65-78.

71. Batool, S.S.; Bond, R. Mediational role of parenting styles in emotional intelligence of parents and aggression among adolescents. Int. J. Psychol. 2015, 50, 240-244. [CrossRef] [PubMed]

72. Salovey, P.; Bedell, B.; Detweiler, J.B.; Mayer, J.D. Current directions in emotional intelligence research. In Handbook of Emotions, 2nd ed.; Lewis, M., Haviland-Jones, J.M., Eds.; Guilford Press: New York, NY, USA, 2000; pp. 504-520.

73. Lekaviciene, R.; Antiniene, D. High emotional intelligence: Family psychosocial factors. Procedia Soc. Behav. Sci. 2016, 217, 609-617. [CrossRef]

74. Domínguez, E.M.; Fortich, D.; Rosero, A.L. Competencias parentales y resiliencia infantil en contexto de desplazamiento en Colombia. Prism. Soc. 2018, 20, 227-253.

75. Galdiolo, S.; Roskam, I. From me to us: The construction of family alliance. Infant Ment. Health J. 2016, 37, 29-44. [CrossRef] [PubMed]

76. Alibakhshi, H.; Mahdizadeh, F.; Siminghalam, M.; Ghorbani, R. The Effect of Emotional Intelligence on the Quality of Life of Mothers of Children with Autism. Middle East J. Rehabil. Health 2018, 5, e12468. [CrossRef]

77. Premanand, V.; Kumari, K.K.; Mathew, T.P. Trait Emotional Intelligence among the parents of children with autism and typically developing children. Indian J. Health Wellbeing 2014, 5, 1009. 
78. Fornia, G.L.; Frame, M.W. The social and emotional needs of gifted children: Implications for family counseling. Fam. J. 2001, 9, 384-390. [CrossRef]

79. Lee, S.Y.; Olszewski-Kubilius, P. The Emotional Intelligence, Moral Judgment, and Leadership of Academically Gifted Adolescents. J. Educ. Gift. 2006, 30, 29-67. [CrossRef]

80. Zeidner, M.; Matthews, G.; Roberts, R.D.; MacCann, C. Development of emotional intelligence: Towards a multi-level investment model. Hum Dev. 2003, 46, 69-96. [CrossRef]

81. Sánchez-Álvarez, N.; Extremera, N.; Fernández-Berrocal, P. The relation between emotional intelligence and subjective well-being: A meta-analytic investigation. J. Posit. Psychol. 2016, 11, 276-285. [CrossRef]

82. Brajsa-Zganec, A.; Lipovcan, L.K.; Ivanovic, D.; Larsen, Z.P. Well-being of nursing students: Role of affect regulation, self-esteem, family cohesion and social support. Open Public Health J. 2017, 10, 69-79. [CrossRef]

83. Vicente-Galindo, M.P.; López-Herrera, H.; Pedrosa, I.; Suárez-Álvarez, J.; Galindo-Villardón, M.P.; García-Cueto, E. Estimating the effect of emotional intelligence in wellbeing among priests. Int. J. Clin. Health Psychol. 2017, 17, 46-55. [CrossRef] [PubMed]

84. Zeidner, M.; Matthews, G.; Shemesh, D.O. Cognitive-social sources of wellbeing: Differentiating the roles of coping style, social support and emotional intelligence. J. Happiness Stud. 2016, 17, 2481-2501. [CrossRef]

85. Zeidner, M.; Matthews, G.; Roberts, R.D. The emotional intelligence, health, and well-being nexus: What have we learned and what have we missed? Appl. Psychol. Health Well Being 2012, 4, 1-30. [CrossRef] [PubMed]

86. Platsidou, M.; Tsirogiannidou, E. Enhancement of emotional intelligence, family communication, and family satisfaction via a parent educational program. J. Adult Dev. 2016, 23, 245-253. [CrossRef]

87. Cejudo, J.; García-Castillo, F.J.; Luna, P.; Rodrigo-Ruiz, D.; Feltrero, R.; Moreno-Gómez, A. Using a Mindfulness-Based Intervention to Promote Subjective Well-Being, Trait Emotional Intelligence, Mental Health, and Resilience in Women with Fibromyalgia. Front. Psychol. 2019, 10, 2541. [CrossRef]

88. Gutiérrez-Cobo, M.J.; Cabello, R.; Fernández-Berrocal, P. The relationship between emotional intelligence and cool and hot cognitive processes: A systematic review. Front. Behav. Neurosci. 2016, 10, 101. [CrossRef]

89. Di Fabio, A.; Kenny, M.E. Promoting well-being: The contribution of emotional intelligence. Front. Psychol 2016, 7, 1182. [CrossRef] [PubMed]

90. Chow, S.M.; Ram, N.; Boker, S.M.; Fujita, F.; Clore, G. Capturing weekly fluctuation in emotion using a latent differential structural approach. Emotion 2005, 5, 208-225. [CrossRef] [PubMed]

91. Lucas, R.; Diener, E. Personality and Subjective Well-Being. In The Science of Well-Being. Social Indicators Research Series; Diener, E., Ed.; Springer: New York, NY, USA, 2009; Volume 37, pp. 75-102.

92. Joseph, D.L.; Chan, M.Y.; Heintzelman, S.J.; Tay, L.; Diener, E.; Scotney, V.S. The manipulation of affect: A meta-analysis of affect induction procedures. Psychol. Bull. 2020, 146, 355. [CrossRef]

93. Abbas, J.; Aqeel, M.; Wenhong, Z.; Aman, J.; Zahra, F. The moderating role of gender inequality and age among emotional intelligence, homesickness and development of mood swings in university students. Int. J. Hum. Rights Healthc. 2018, 11, 356-367. [CrossRef]

94. Fredrickson, B.; Joiner, T. Positive emotions trigger upward spirals toward emotional well-being. Psychol. Sci. 2002, 13, 172-175. [CrossRef] [PubMed]

95. Heintzelman, S.J.; Diener, E. Subjective well-being, social interpretation, and relationship thriving. J. Res. Pers. 2019, 78, 93-105. [CrossRef]

96. Rinn, A.; Majority, K. The Social and Emotional World of the Gifted. In Handbook of Giftedness in Children: Psychoeducational Theory, Research, and Best Practices, 2nd ed.; Pfeiffer, S., Ed.; Springer: Tallahassee, FL, USA, 2018; pp. 49-63.

97. Peterson, J.S. Myth 17: Gifted and talented individuals do not have unique social and emotional needs. Gift Child Q. 2009, 53, 280-282. [CrossRef]

98. Lennard, A.C.; Scott, B.A.; Johnson, R.E. Turning frowns (and smiles) upside down: A multilevel examination of surface acting positive and negative emotions on well-being. J. Appl. Phycol. 2019, 104, 1164. [CrossRef]

99. Etikan, I.; Musa, S.A.; Alkassim, R.S. Comparison of Convenience Sampling and Purposive Sampling. Am. J. Theor. Appl. Stat. 2016, 5, 1-4. [CrossRef]

100. Diener, E.; Wirtz, D.; Tov, W.; Kim-Prieto, C.; Choi, D.; Oishi, S.; Biswas-Diener, R. New measures of well-being: Flourishing and positive and negative feelings. Soc. Indic. Res. 2009, 39, 247-266. 
101. Salovey, P.; Mayer, J.D.; Goldman, S.L.; Turvey, C.; Palfai, T.P. Emotional attention, clarity, and repair: Exploring emotional intelligence using the Trait Meta-Mood Scale. In Emotion, Disclosure, and Health; Pennebaker, J.W., Ed.; American Psychological Association: Washington, DC, USA, 1995; pp. 125-154.

102. Podsakoff, P.M.; MacKenzie, S.B.; Lee, J.; Podsakoff, N.P. Common Method Biases in Behavioral Research: A Critical Review of the Literature and Recommended Remedies. J. Appl. Psychol. 2003, 88, 879-903. [CrossRef]

103. Diener, E.; Wirtz, D.; Tov, W.; Kim-Prieto, C.; Choi, D.W.; Oishi, S.; Biswas-Diener, R. New well-being measures: Short scales to assess flourishing and positive and negative feelings. Soc. Indic. Res. 2010, 97, 143-156. [CrossRef]

104. Cassaretto, M.; Martínez, P. Validación de las escalas de bienestar, de florecimiento y afectividad. Pensam. Psicol. 2017, 15, 19-31.

105. Fernández-Berrocal, P.; Extremera, N.; Ramos, N. Validity and reliability of the Spanish modified version of theTrait Meta-Mood Scale. Physiol. Rep. 2004, 94, 751-755.

106. Górriz, A.B.; Etchezahar, E.; Pinilla-Rodríguez, D.E.; Giménez-Espert, M.D.C.; Prado-Gascó, V. Cross-cultural validation of the Mood Questionnaire in three Spanish-speaking countries Argentina, Ecuador, and Spain. J. Soc. Psychol. 2020, 1-17. [CrossRef] [PubMed]

107. Fujita, F.; Diener, E. Life satisfaction set-point: Stability and change. J. Pers. Soc. Psychol. 2005, 88, $158-164$. [CrossRef] [PubMed]

108. Hair, J.F.; Money, A.H.; Samouel, P.; Page, M. Research Methods for Business; John Wiley and Sons: Hoboken, NJ, USA, 2007.

109. Shi, D.; Lee, T.; Maydeu-Olivares, A. Understanding the Model Size Effects on SEM Fit Indices. Educ. Psychol. Meas. 2018, 79, 310-334. [CrossRef] [PubMed]

110. Hooper, D.; Coughlan, J.; Mullen, M. Structural Equation Modelling: Guidelines for Determining Model Fit. Electron. J. Bus. Res. Metod. 2008, 6, 53-60.

111. Newsom, J.T. Some Clarifications and Recommendations on Fit Indices. Available online: http://web.pdx. edu/ \{\}newsomj/semclass/ (accessed on 1 September 2020).

112. Hu, L.T.; Bentler, P.M. Cutoff Criteria for Fit Indexes in Covariance Structure Analysis: Conventional Criteria Versus New Alternatives. Struct. Equ. Modeling 1999, 6, 1-55. [CrossRef]

113. Kyriazos, T.A. Applied Psychometrics: Sample Size and Sample Power Considerations in Factor Analysis (EFA, CFA) and SEM in General. Psychology 2018, 9, 2207-2230. [CrossRef]

114. MacCallum, R.C.; Browne, M.W.; Sugawara, H.M. Power analysis and determination of sample size for covariance structure modeling. Psychol. Methods 1996, 1, 130. [CrossRef]

115. Kenny, D.; Kaniskan, B.; McCoach, D.B. The Performance of RMSEA in Models with Small Degrees of Freedom. Soc. Methods Res. 2015, 44, 486-507. [CrossRef]

116. Taasoobshirazi, G.; Wang, S. The performance of the SRMR, RSEA, CFI, and TLI: An examination of sample size, path size, and degrees of freedom. J. Appl. Quant. Methods 2016, 11, 31-40.

117. MacKinnon, D.P.; Lockwood, C.M.; Hoffman, J.M.; West, S.G.; Sheets, V.A. Comparison of methods to test mediation and other intervening variable effects. Psychol. Methods 2002, 7, 83-104. [CrossRef] [PubMed]

118. Mathieu, J.E.; Taylor, S.R. Clarifying conditions and decision points for mediational type inferences in organizational behavior. J. Organ. Behav. 2006, 27, 1031-1056. [CrossRef]

119. Preacher, K.J.; Kelley, K. Effect Size Measures for Mediation Models: Quantitative Strategies for Communicating Indirect Effects. Psychol. Methods 2011, 16, 93-115. [CrossRef] [PubMed]

120. Hair, J.; Black, W.C.; Babin, B.J.; Anderson, R.E. Multivariate Data Analysis, 7th ed.; Pearson: Upper Saddle River, NJ, USA, 2010.

121. Greenspoon, P.J.; Sasklofske, D.H. Toward an integration of SWB and psychopathology. Soc. Indic. Res. 2001, 54, 81-108. [CrossRef]

122. Fernández-Castillo, A.; Vilchez-Lara, M.J. Factores desencadenantes de insatisfacción e ira en padres de niños atendidos en servicios de urgencias pediátricos. An. Pediatr. 2015, 82, 12-18. [CrossRef] [PubMed]

123. Goleman, D. Inteligencia Emocional; Kairós: Barcelona, Spain, 1996.

124. Sánchez-García, M.D.L.Á.; Lucas-Molina, B.; Fonseca-Pedrero, E.; Pérez-Albéniz, A.; Paino, M. Emotional and behavioral difficulties in adolescence: Relationship with emotional well-being, affect, and academic performance. An. Psicol. 2018, 34, 482-489.

125. Evenson, R.J.; Simon, R.W. Clarifying the relationship between parenthood and depression. J. Health Soc. Behav. 2005, 46, 341-358. [CrossRef] 
126. Salgado, J.F.; Blanco, S.; Moscoso, S. Subjective well-being and job performance: Testing of a suppressor effect. J. Work Organ. Psychol. 2019, 35, 93-102. [CrossRef]

127. Suldo, S.M.; Thalji-Raitano, A.; Kiefer, S.M.; Ferron, J.M. Conceptualizing High School Students' Mental Health Through a Dual-Factor Model. Sch. Psych. Rev. 2016, 45, 434-457. [CrossRef]

128. Sahuquillo, P.; Ramos, G.; Pérez, A.; Camino, A.I. Las competencias parentales en el ámbito de la identificación/evaluación de las altas capacidades. Profesorado 2016, 20, 200-217.

129. Sánchez, C.N.P.; Montesinos, M.B.; Rodríguez, L.C. Influencias de la familia en el rendimiento académico. Un estudio en Canarias. Rev. Int. Sociol. 2013, 71, 169-187.

130. Estadísticas del Ministerio de Educación, Curso 2017-2018. Available online: https://www.educacionyfp.gob. es/servicios-al-ciudadano/estadisticas/indicadores-publicaciones-sintesis/cifras-educacion-espana/201718.html (accessed on 20 March 2020).

131. Cadman, D.; Rosenbaum, P.; Boyle, M.; Offord, D. Children with Chronic Illness: Family and Parent Demographic Characteristics and Psychosocial Adjustment. Pediatrics 1991, 87, 884-889. [PubMed]

132. Pati, S.P. Development of a Measure of Employee Engagement. Indian J. Ind. Relat. 2012, 48, 94-104.

133. Lee, Z.; Sargeant, A. Dealing with social desirability bias: An application to charitable giving. Eur. J. Mark. 2011, 45, 703-719. [CrossRef]

134. Mitchell, M.L.; Jolley, J.M. Research Design Explained; Wadsworth: Belmont, CA, USA, 2010.

135. Nederhof, A.J. Methods of coping with social desirability bias: A review. Eur. J. Soc. Psychol. 1985, 15, 263-280. [CrossRef]

136. Martín, F.; Ledesma, R.D.; Montes, S.A. Propiedades psicométricas de la escala de deseabilidad social del conductor. Aval. Psicol. 2010, 9, 299-310.

137. Azizan, N.H.B.; Mahmud, Z.B. A systematic review on determinants of subjective well-being. Environ. Behav. Proc. J. 2018, 3, 1-9. [CrossRef]

138. Larsen, R.J.; Eid, M. Ed Diener and the Science of Subjective Well-Being. In The Science of Subjective Well-Being; Eid, M., Larsen, R.J., Eds.; Guilford: New York, NY, USA, 2008; pp. 1-13.

Publisher's Note: MDPI stays neutral with regard to jurisdictional claims in published maps and institutional affiliations.

(C) 2020 by the authors. Licensee MDPI, Basel, Switzerland. This article is an open access article distributed under the terms and conditions of the Creative Commons Attribution (CC BY) license (http://creativecommons.org/licenses/by/4.0/). 